\title{
PERANG PASIFIK DI PULAU MOROTAI: REKONSTRUKSI INFRASTRUKTUR DAN STRATEGI PERANG
}

\author{
Pacific War in Morotai Island: \\ Reconstruction of Infrastructure and War Strategy
}

\author{
Wuri Handoko ${ }^{1}$, Godlief Arsthen $\mathbf{P}^{2}$, Cheviano Alputila ${ }^{3}$ \\ ${ }^{1,2}$ Balai Arkeologi Maluku \\ J1. Namalutu-Latuhalat, Ambon, Indonesia \\ wuri.handoko@kemdikbud.go.id \\ ${ }^{3}$ Balai Pelestarian Cagar Budaya Ternate \\ J1. R. Pertamina, Kel. Jumbula, Kec. Pulau Ternate, Kota Ternate, Indonesia
}

\begin{abstract}
Naskah diterima: 29/03/2018; direvisi: 01/04-21/05/2018; disetujui: 20/07/2018
Publikasi ejurnal: 31/07/2018
\end{abstract}

\begin{abstract}
Pacific war in Morotai is an important historical event in Indonesia as well as in the world. The Pacific war involving two major powers, the Allies and Japan, left a trail of archaeological studies examined to record a very important historical event in the Pacific region of Morotai Island. Based on the concept of military archaeology, this study uses archaeological data to reconstruct infrastructure and allied strategies in combat against Japan. Investigation of these remains proceeded through studying textual and photographic records on the Allies' occupation of Morotai Island, and examination of modern-day aerial photographs of the terrain where the Allies built their infrastructure, followed by archaeological survey and through interviewing local residents to describe traces of the Pacific war infrastructure.The results explain that the preparation of good infrastructure by the allies is part of the war strategy, which determines the win for the allies against the Japanese.
\end{abstract}

Keyword: Military archaeology, infrastructure, strategy.

\begin{abstract}
Abstrak
Perang pasifik di Morotai merupakan peristiwa sejarah yang penting di Indonesia dan juga di dunia. Perang Pasifik yang melibatkan dua kekuatan besar, Sekutu dan Jepang, meninggalkan jejak arkeologi peperarangan yang dikaji untuk merekam peristiwa sejarah yang sangat penting di kawasan pasifik di Pulau Morotai. Berdasarkan konsep military archaeology, penelitian ini menggunakan data arkeologi untuk merekonstruksi infrastruktur dan strategi sekutu dalam pertempuran melawan Jepang. Investigasi arkeologi dilakukan dengan mempelajari catatan tekstual dan fotografis tentang pendudukan Pulau Morotai oleh Sekutu, dan pemeriksaan foto-foto udara modern di daerah Sekutu membangun infrastruktur, dan selanjutnya melakukan survei arkeologi dan wawancara penduduk setempat untuk menggambarkan jejak infrastrukutr perang pasifik. Hasil penelitian menjelaskan bahwa penyiapan insfrastruktur dengan baik oleh pihak sekutu merupakan bagian dari strategi perang, yang menentukan kemenangan bagi pihak sekutu dalam melawan Jepang.
\end{abstract}

Kata Kunci: Arkeologi peperangan, infrastruktur, strategi.

\section{PENDAHULUAN}

Salah satu babakan dalam perang pasifik adalah, terjadinya pertempuran antara pihak Sekutu (Amerika, Inggris, Australia dan Belanda) dengan Jepang di Pulau Morotai dalam rangka menaklukkan Jepang di Filipina. Meski demikian, nama
Morotai tampaknya belum begitu banyak dibahas. Dalam Sejarah Nasional Indonesia (SNI), Morotai sebagai wilayah dalam fase sejarah perang Pasifik di Asia Tenggara, tidak disebut sama sekali dalam sejarah nasional Indonesia (Rahman, n.d., p. 27). Secara geografis wilayah Maluku Utara 
yang berbatasan langsung dengan Kawasan Pasifik, membuat posisi Pulau Morotai dari aspek geopolitik sangat strategis sewaktu terjadi Perang Asia Timur Raya atau Perang Pasifik (Djafaar, 2005, pp. 57-58).

Pulau Morotai merupakan kawasan yang dianggap strategis sehingga dalam Perang Pasifik, Jenderal Douglas MacArthur memilih sebagai lokasi untuk pangkalan udara dan fasilitas angkatan laut yang diperlukan untuk operasi pembebasan Mindano, pada bulan 15 September 1944 (Smith, 1953, pp. 450-451). Pada awal tahun 1944, Morotai muncul sebagai wilayah yang penting bagi militer Jepang ketika mulai mengembangkan pulau-pulau di Halmahera sebagai titik fokus untuk mempertahankan pendekatan selatannya ke Filipina. Pada bulan Mei 1944, Divisi ke-32 Angkatan Darat Kekaisaran Jepang tiba di Halmahera untuk mempertahankan pulau dan sembilan landasan udaranya (Smith, 1953, p. 460). Divisi ini telah mengalami kerugian besar ketika konvoi yang membawanya dari China (konvoi Take Ichi) diserang oleh kapal selam AS (Willoughby, 1966, p. 270).

Salah satu wilayah yang diinginkan Jepang adalah wilayah Hindia Belanda (Indonesia). Ketidakmampuan pemerintah Belanda dalam menghadapi militer Jepang menyebabkan pemerintah Belanda menyerah kepada pasukan Jepang pada 8 Maret 1942 (Parera, Usmany, \& Sinaga, 2013, p. 1). Berbagai catatan-catatan sejarah yang ada, maka kajian ini menitikberatkan pada data arkeologis untuk mengungkap dan merekonstruksi perang pasifik, terutama dalam konteks pembangunan dan pemanfaatan insfrastruktur perang kota yang bukti-bukti arkeologinya masih bisa dijumpai hingga sekarang. Dalam kerangka perspektif arkeohistoris, informasi tentang keberadaan bukti-bukti arkeologis periode Perang Dunia II belum banyak diketahui. Informasi-informasi tentang bentuk-bentuk sarana pertahanan, termasuk lokasi keberadaannya, serta latar historis keberadaan sarana pertahanan tersebut. Pada akhirnya informasi bukti-bukti arkeologis tersebut dapat memberi pemahaman tentang periode Perang Dunia II (Mansyur, 2012, p. 44).

Pada Januari 1945 tentara sekutu berhasil mengetahui posisi dua batalion tentara Jepang dari resimen ke 211 pada "Hill 40". Lokasinya adalah sekitar $6 \mathrm{~km}$ di sisi utara parimeter yang dibuat sekutu. Penyerangan oleh tentara sekutu dimulai pada 3 Januari 1945. Aksi ini dilaksanakan oleh Batalion 1 dan ke-2 dari Resimen Infantri ke-136. Dua batalion ini masuk menuju "Hill 40" dari sisi barat laut dan menemui perlawanan sengit dari tentara Jepang. Keesokan harinya, Tentara sekutu memanfaatkan bantuan artileri dan dukungan perbekalan yang didatangkan lewat udara (kemungkinan besar menggunakan helikopter). Pada siang hari serangan artileri sudah bisa mencapai markas tentara Jepang di "Hill 40". Pada waktu itu tentara sekutu (Batalion ke-3 dari Resimen 136) masuk ke "Hill 40" melalui sisi utara dan menghancurkan tentara Jepang (Batalion ke-3 dari Resimen ke-211) dalam beberapa pertarungan. Batalion ke-3 dari Resimen ke-211 ditempatkan di pesisir pantai untuk menerima perbekalan dari Halmahera dan meluncurkan beberapa serangan yang tidak sukses kepada tentara sekutu yang bergerak menuju pantai setelah tentara Jepang mendarat pada Desember di Morotai (Smith, 1953; William P. Endicott, 1997, p. 48).

Penelitian ini menekankan pada data arkeologi untuk memberikan gambaran fakta sejarah tentang perang pasifik di Morotai. Istilah perang Pasifik umumnya dikenal oleh para penulis Eropa, yakni "Pacific War" atau "Pacific Teather" dalam literatur Jepang mengenal perang ini dengan istilah " Perang Asia Timur Raya" (Murray \& Millett, 2001, p. 143; Takou, 2015, p. 3). Secara spasial wilayah-wilayah yang terlibat dalam perang ini menurut penjelasan Gordon dalam bukunya "Pacific Island 
Guide" yakni: Pasifik Tengah, Pasifik Selatan, Pasifik Barat Daya, Pasifik Barat, dan Pasifik Utara (Rottman, 2002; Takou, 2015 , p. 3). Sumber-sumber buku yang bisa memberikan informasi keadaan Morotai pada periode September 1944 hingga September 1945 sebagaimana yang diuraikan oleh Takou (2015) antara lain adalah karya Robert Ross Smith "The Approach to The Philippines", pada bab XIX memberikan cukup keterangan tentang perencanaan strategis dan taktis serta mengamankan dan mengembangkan pulau Morotai (Smith, 1953, pp. 459-491). Sumber lain yang bisa memberikan informasi yakni, karya Gordon L Rottman "World War II Pasific Island Guide" buku yang menggambarkan keterlibatan pulaupulau dalam perang Pasifik terutama pulaupulau di Pasifik Barat Daya dan Pulau Morotai adalah salah satunya. Namun, secara keseluruhan pada bagian yang membahas pulau Morotai, isinya tidak berbeda jauh dengan tulisan Robert Smith (Rottman, 2002, pp. 227-253). Sementara tulisan Odger George dalam buku "Air War Against Japan 1943-1945" dan tulisan Gill Hermon dalam buku, "Royal Australian Navy 1942-1945" juga menjelaskan informasi yang sama dengan dua penulis sebelumnya (Hermon, 1968, pp. 481-488; Takou, 2015, p. 3).

Beberapa karya lain misalnya Air Force Combat Unit of World War II tentang unit-unit tempur yang dikerahkan Amerika Serikat dalam perang Pasifik termasuk serangan atau invasi ke Morotai dan waktu penyerangannya (Maurer, 1983). Karya lain yang cukup penting misalnya, General Kenney Report. Apersonal History of the Pacific War, yang ditulis sendiri oleh pelaku sejarah, yakni George C Kenney. Dalam laporan itu juga diuraikan tentang rencana yang sudah terjadwal penyiapan serangan udara di wilayah Morotai untuk menguasai Filipne (Kenney, 1997, pp. 411-415). Selain itu tentu masih banyak karya tulis lain baik dalam bentuk artikel singkat maupun sebuah laporan biografi dan karya riset lainnya tentang Perang Pasifik atau Perang Dunia II.

Di Indonesia sendiri, penelitian dan karya tulis yang spesifik membahas tentang Morotai sangat minim. Berdasarkan penelusuran pustaka, karya tulis tentang sejarah perang pasifik pada umumnya memberikan gambaran tentang peristiwaperistiwa yang terjadi pada perang pasifik yang melibatkan tentara sekutu dengan Jepang, namun tidak secara khusus membahas tentang keberadaan peninggalan fisik perang itu sendiri dan fenomena perangnya itu sendiri. Kalaupun ada buktibukti fisik jejak perang pasifik yang ditampilkan tidak terfokus mendeskripsikan lebih detail untuk menjelaskan fungsi-fungsi tinggalan fisik pada masa digunakannya. Beberapa penelitian yang sudah dilakukan diantaranya, Abdul Rahman yang meneliti tentang sejarah perang pasifik. Dalam karya tulisnya, ia mendeskripsikan atau mereview peristiwa-peristiwa perang pasifik berdasarkan sumber-sumber pustaka dan wawancara (Rahman, n.d.). Karya tulis tentang perang pasifik yang menekankan pada data arkeologi dilakukan oleh Syahruddin Mansyur, yang menjelaskan tentang keberadaan tinggalan arkeologi Perang Dunia II di Morotai dalam kerangka pengembangannya sebagai museum situs (Mansyur, 2013). Dengan demikian, perspektif arkeologis untuk mengungkap dan merekonstruksi perang pasifik sebagai sebuah peristiwa sejarah, sesungguhnya belum dikaji secara khusus.

Studi tentang perang dalam arkeologi mewakili suatu kasus khusus penelitian yang menempatkan arti penting dari peristiwa yang telah hilang, melampaui pentingnya kesaksian yang diperoleh di lapangan (Vencl, 1984, pp. 116-117). Situssitus yang terkait dengan usaha militer lainnya telah ditemukan dan budaya material konflik telah didokumentasikan. Pertumbuhan ini telah memperluas pemahaman tentang konflik masa lalu dan menantang gagasan yang sebelumnya 
digunakan tentang sebuah tentang peristiwa peperangan (Bleed \& Scott, 2011, pp. 116117). Berdasarkan konsepsi tentang arkeologi peperangan (military archaeology), serta catatan-catatan sejarah tentang perang pasifik di Morotai yang sudah diuraikan tersebut, maka rumusan permasalahan dalam kajian ini dapat diuraikan dalam pertanyaan penelitian, sebagai berikut: 1). bagaimana tinggalan arkeologi pada masa lampau sebagai bukti infrastruktur perang digunakan pada Perang Pasifik di Morotai? 2). Bagaimana strategi perang pasifik yang dipraktekkan oleh sekutu berdasarkan jejak arkeologi ? Dengan demikian tujuan dari penulisan ini adalah untuk mendeksripsikan dan mengkaji jejakjejak arkeologis yang diidentifikasikan sebagai infratruktur perang dalam peristiwa perang pasifik di Morotai. Selain itu berdasarkan sebaran data arkeologi jejak perang dan peta lama masa perang dunia II di Morotai, juga dimaksudkan untuk mendeskripsikan strategi perang yang dilakukan pihak Sekutu dalam memenangkan pertempuran dengan Jepang di Morotai dalam upaya invasinya ke wilayah Filipina.

\section{METODE PENELITIAN}

Penelitian ini dilakukan pada umumnya dengan melakukan survei, wawancara dan studi pustaka, terutama melihat dokumen-dokumen yang menjelaskan tentang perang pasifik di Morotai. Selain itu, juga menelusuri petapeta lama pada masa kedatangan Jepang dan Sekutu. Dari hasil olah peta lama dan peta satelit, ditelusuri toponim dan lokasi-lokasi yang menunjukkan jejak-jejak perang pasifik. Untuk mempermudah olah peta dan gambar, maka foto digital dan olah foto drone, merupakan data penelitian yang sangat penting. Hal ini karena olah foto drone dapat digunakan untuk merekonstruksi dimensi dan bentuk struktur atau fitur tinggalan perang pasifik. Olah foto drone dan olah peta lama, juga dapat digunakan untuk melihat perbandingan Pulau Morotai pada masa kini dan pada masa perang pasifik, sekaligus untuk melihat jejak-jejak perang pasifik yang masih dapat dilihat hingga kini, baik kondisi lanskap, lingkungan maupun morfologi pemukiman yang ada sekarang. Seluruh data ini diverifikasi dengan dokumen-dokumen yang bisa ditelusuri dari berbagai sumber. Sebaliknya juga, dokumen-dokumen yang ada mempermudah penelusuran data secara arkeologis.

Berdasar sumber dokumen-dokumen dan peta lama kondisi Pulau Morotai pada masa perang pasifik dan juga hasil wawancara-wawancara dengan sumber yang masih terbatas, maka dilakukan survei arkeologi untuk mengidentifikasi peninggalan perang pasifik di Pulau Morotai. Peta lama Morotai, pada saat perang pasifik pada tanggal 15 September 1944, merupakan sumber awal untuk menelusuri lebih jauh peninggalan perang pasifik di Pulau Morotai. Selanjutnya, melakukan pencocokan dan verifikasi peta lama dengan hasil survei dan observasi lapangan dari kondisi yang ada sekarang. Berdasarkan analisis temuan arkeologi jejak perang dan peta sebarannya, serta analogi sejarah baik catatan sejarah tertulis maupun hasil wawancara, maka dibangun interpretasi untuk merekonstruksi penggunaan infrastruktur dan stratetegi perang yang diterapkan.

\section{HASIL DAN PEMBAHASAN}

\section{Jejak Arkeologi Infrastruktur Perang Pasifik di Morotai}

Peristiwa perang pasifik di Morotai, meskipun berlangsung relatif singkat, namun berdampak luas terhadap perkembangan sejarah dan kehidupan sosial penduduk. Perencanaan pembangunan lapangan udara dan instalasi dasar lainnya dilakukan sebelum pendaratan, dan lokasi fasilitas militer sementara telah dipilih pada 15 September ("Airfield and Base 


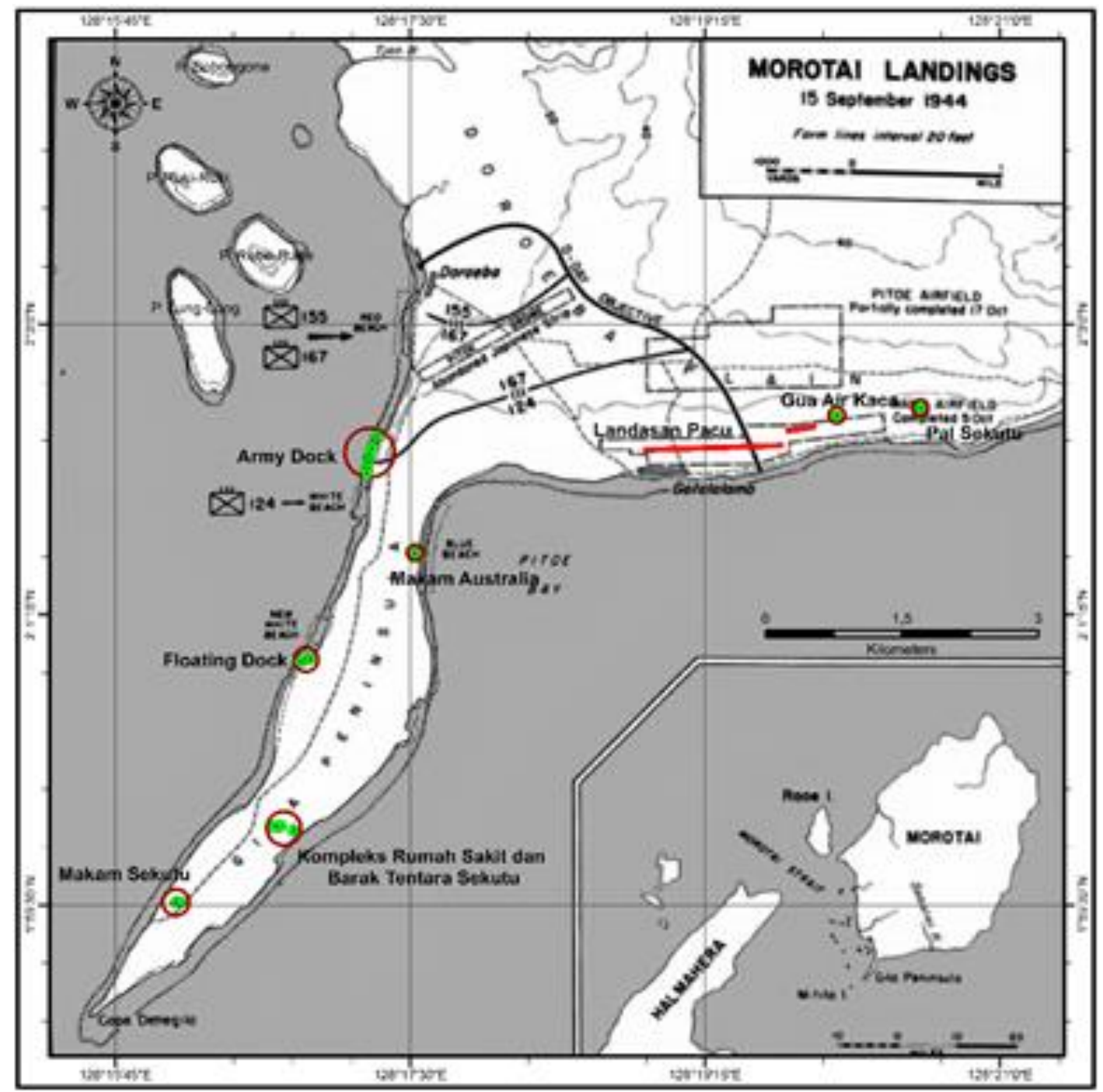

Gambar 1. Hasil registrasi dan overlay peta pendaratan pasukan sekutu dalam pertempuran Morotai (Battle of Morotai) pada hari pertama 15 September 1944 dengan plotting peningalan arkeologis.

(Sumber: Dokumentasi Smith, 1953: 476).

Development. Engineers of the Southwest Pacific," 1951, p. 272).

\section{a. Army Dock}

Dalam sebuah operasi pertempuran, yang dikenal dengan Tradewind, selain pasukan tempur, sekutu juga mengikutsertakan pekerja konstruksi dalam jumlah yang besar dan unit-unit ahli komunikasi yang berperan untuk mempercepat perkembangan Pulau Morotai menjadi basis utama penyerangan sekutu terhadap pangkalan militer Jepang di Filipina. Satu-satunya hal yang memperlambat pendaratan sekutu adalah kondisi pantai yang buruk, yang sama sekali tidak diprediksi. Informasi intelejen, menyarankan bahwa kondisi red dan white beach mampu untuk didarati oleh tim amfibi. Pada kenyataannya, saran ini adalah saran yang buruk, karena kenyatannya berlumpur dan susah untuk melakukan pendaratan. Pada pagi hari saat pendaratan, tim survei meyakinkan bahwa sisi pantai yang berada pada daerah di bagian selatan pulau morotai, lebih cocok untuk didarati oleh pasukan LST. Pantai ini yang dinamai blue beach (daerah tugu trikora sekarang), menjadi lokasi utama pendaratan 16 sept 1944 (Smith, 1953, pp. 466-481).

Untuk mengatasi hal itu, sekutu membangun sedikitnya 5 buah army dock. 


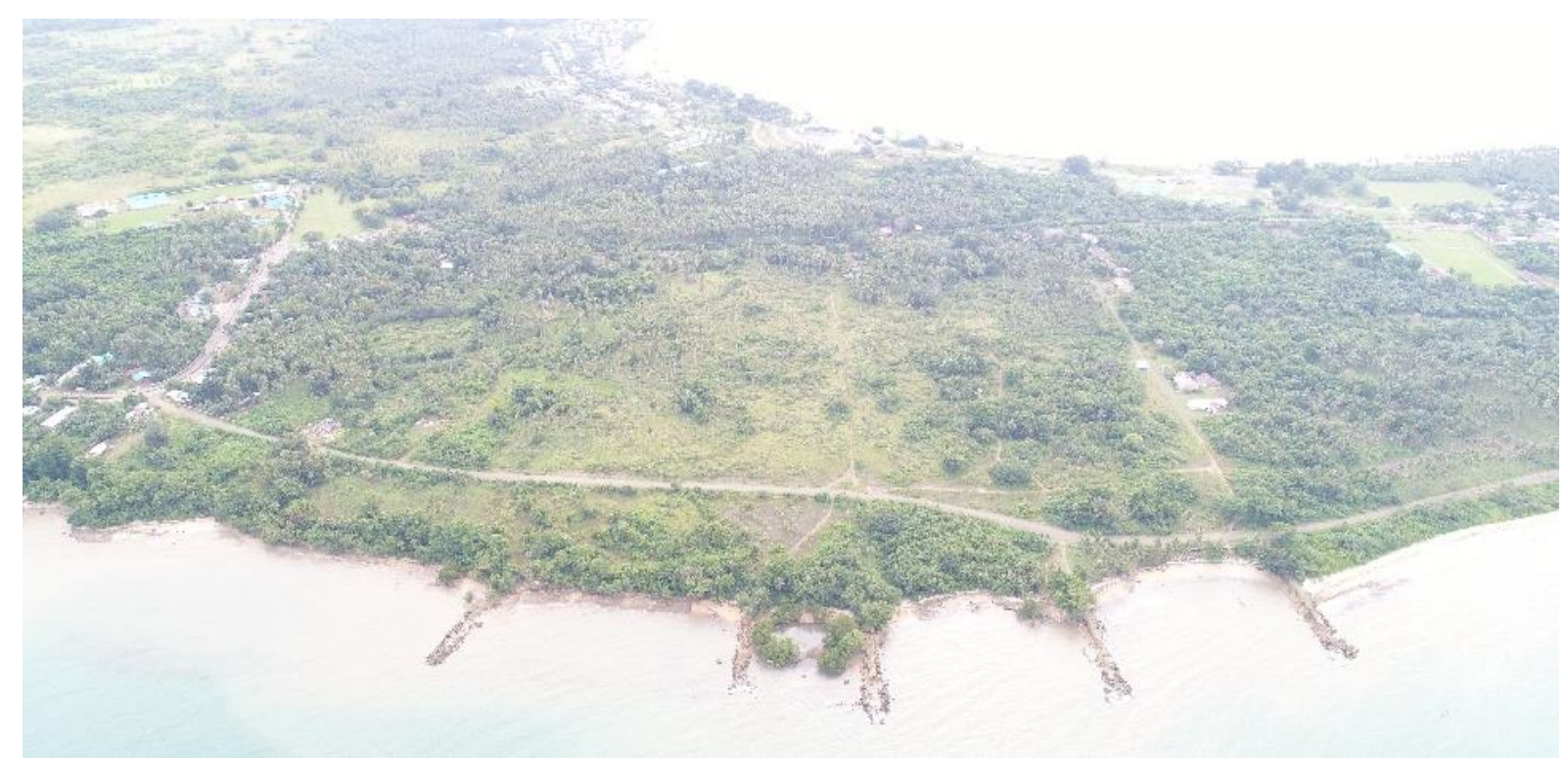

Gambar. 2 Foto drone 5 (lima) buah Army Dock di wilayah pantai yang disebut White Beach pada ketinggian berkisar 200-300m dari permukaan tanah.

(Sumber: Dokumentasi Balar Maluku, 2017)
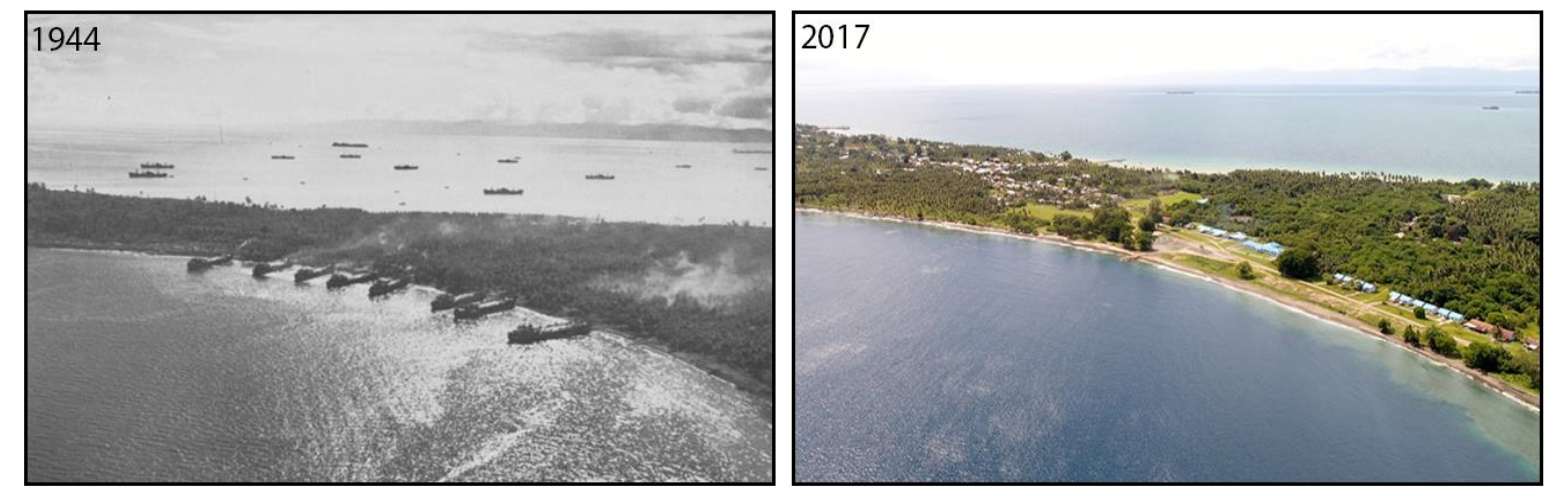

Gambar. 2 Kondisi pantai Blue Beach, lokasi yang aman untuk pendaratan kapal-kapal pengangkut tank (LST) tahun 1944 (kiri) dan kondisi terkini, tahun 2017 (kanan).

(Sumber: gambar kiri : Smith, 1953: 486; gambar kanan: Dokumentasi Balar Maluku, 2017)

berdasarkan identifikasi hasil survei arkeologi yang dikenal sebagai Pantai Putih (White Beach) berada di desa Darame (berada $\pm 2 \mathrm{Km}$ di sebelah utara Floating Dock) (Handoko, Husni, Arsthen, Natasya, \& Kurung, 2017; Huwae, 2017).

Army Dock merupakan salah satu infrastruktur yang penting yang dibangun oleh Sekutu untuk memenuhi kebutuhan fasilitas dalam perang pasifik di Morotai. Berdasarkan analisis yang dilakukan, dapat dikatakan bahwa bahan utama penyusun Army Dock $\left(128^{0} 17\right.$ ' 27,5' BT- $02^{0} 26^{\prime}$ 04" LU) adalah batu gamping terumbu. Jenis batu tersebut berasal dari proses sedimentasi organisme berupa pengumpulan plankton, moluska dan alga yang kemudian membentuk terumbu pada perairan yang dangkal. Hasil rekonstruksi menyimpulkan bahwa garis pantai terbentuk oleh formasi Batu Gamping Terumbu dikeruk untuk digunakan sebagai isian Army Dock. Perubahan garis pantai oleh Tentara Sekutu menjadi cekungan dapat dibuktikan dengan foto drone yang menampakkan cekungancekungan setelah pengerukan. Hasil rekonstruksi juga menyimpulkan bahwa area yang dikeruk hanya pada Army Dock 1 sampai 3. Garis pantai pada Army Dock 4 dan 5 tidak mengalami pengerukan. Survey 


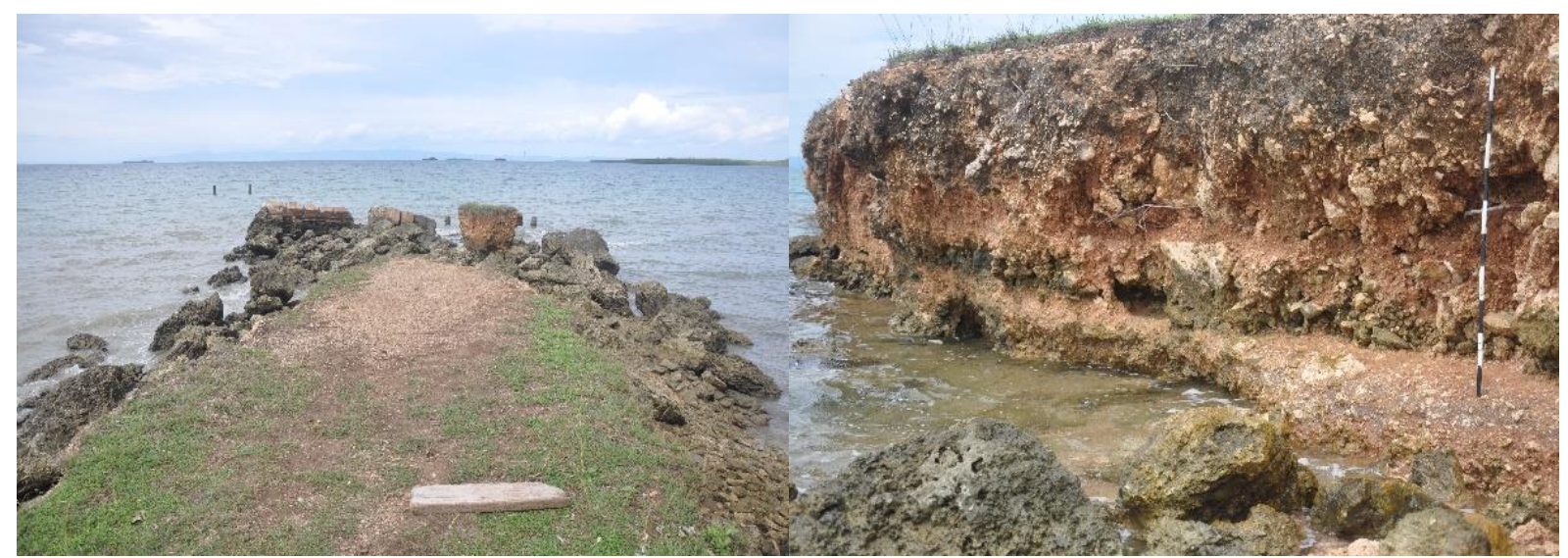

Gambar 3. Penampang Army Dock, yang memperlihatkan Isian terdiri dari gamping terumbu (Sumber: Dokumentasi Balar Maluku, 2017)

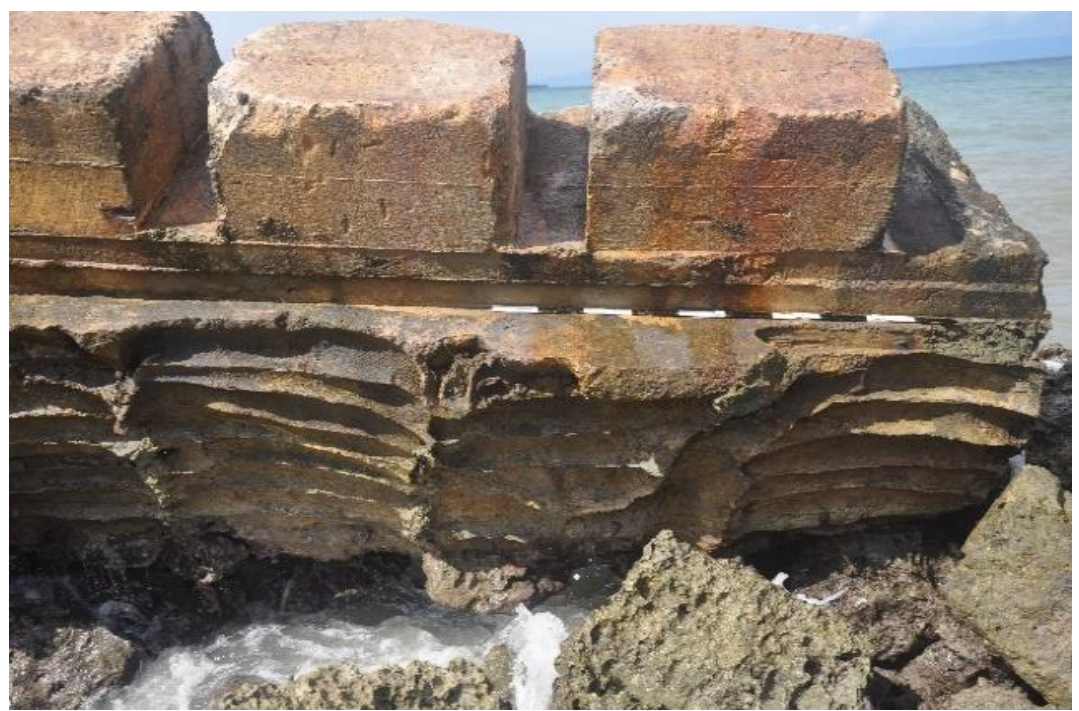

Gambar 4 Bagian depan Army Dock, terdiri dari blok-blok semen untuk tambatan kapal

(Sumber: Dokumentasi Balar Maluku, 2017)

lapangan juga menguatkan kesimpulan tersebut karena formasi batu gamping terumbu hanya terdapat pada garis pantai antara Army Dock 1 sampai army dock 3 sedangkan formasi batu gamping terumbu pada garis pantai antara Army Dock 4 dan 5 tidak terlihat lagi.

Secara sederhana, penggunaan batu gamping terumbu dikarenakan alasan praktis. Sumber daya terdekat yang berada di sekitar lokasi pembuatan Army Dock adalah batu gamping terumbu sehingga tidak mengherankan bahwa sumber daya tersebut yang digunakan sebagai isian Army Dock. Secara struktural, penggunaan batu gamping terumbu sebagai isian akan lebih kuat dibandingkan jenis batu lainnya. Hal ini dikarenakan formasi batu ini mengandung unsur silika yang sama dengan bahan baku pembuat semen. Unsur Silika dalam formasi batu berfungsi sebagai perekat sehingga struktur isian Army Dock masih bertahan hingga saat ini (73 tahun). Pembungkus isian dalam komposisi struktur Army Dock masih belum diketahui secara pasti. Hal ini disebabkan karena proses degradasi/kerusakan yang disebabkan oleh alam atau intervensi manusia. Dugaan kuat struktur pembungkus Army Dock adalah semen atau plat baja. Pada bagian depan Army Dock yang terdapat indikasi struktur 


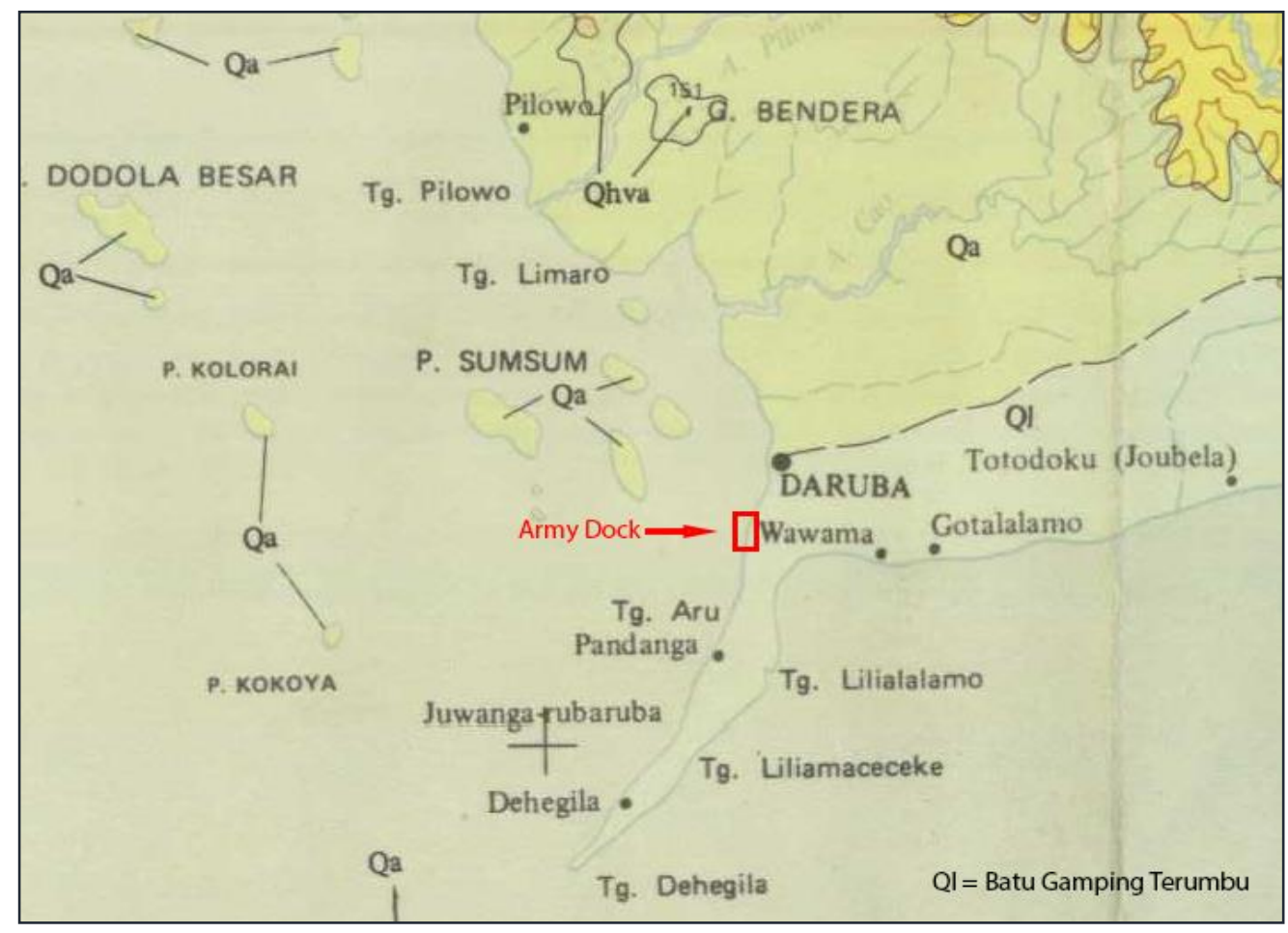

Gambar.5 Peta Geologi yang menunjukkan jenis batuan gamping terumbu pada lokasi dibangunnya Army Dock

(Sumber: Dokumentasi Supriatna Sam dari Puslitbang Geologi, 1993)

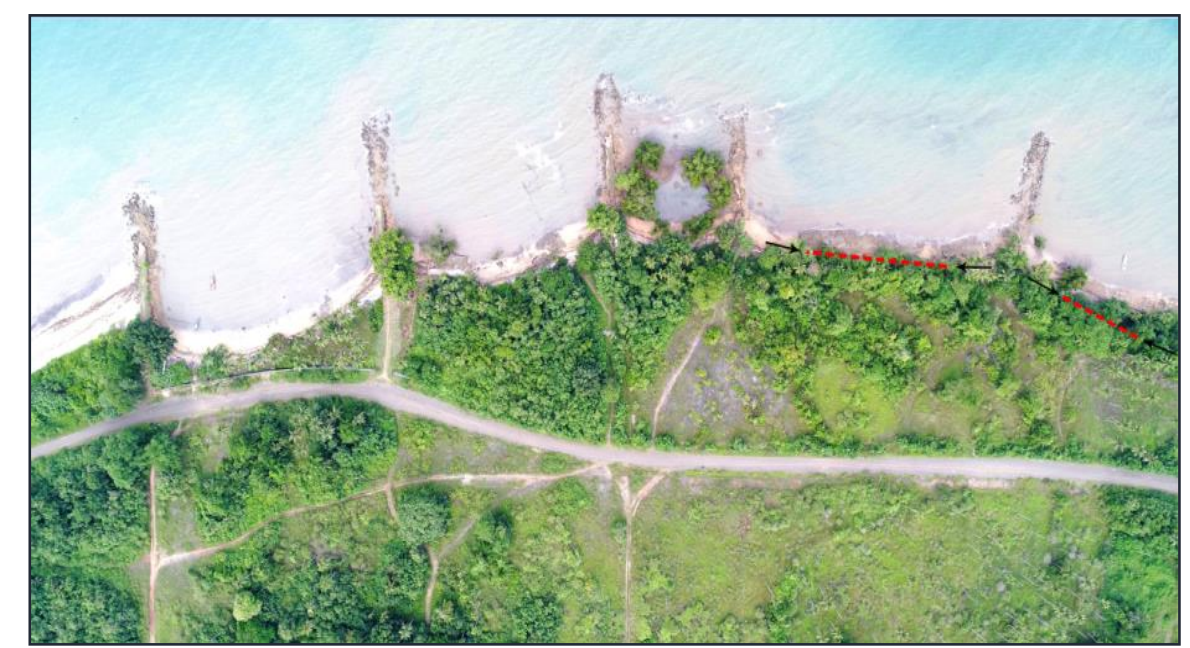

Gambar 6. Foto drone 5 buah army dock yang memperlihatkan cekungan bekas pengerukan garis pantai pada army dock 1-3, sedagkan army dock 4-5, tidak terjadi pengerukan garis pantai, karena 'putus kontak' geologi gamping terumbu.

(Sumber: Dokumentasi Balar Maluku, 2017)

yang berfungsi sebagai penambat kapal berupa blok-blok semen.

Selain lokasi Army dock yang sudah diuraikan sebelumnya, juga melakukan survei di lokasi-lokasi situs lainnya, antara lain floating dock, wama drome, makam sekutu dan makam Australia, kompleks rumah sakit dan barak atau sekutu dan lokasi-lokasi situs peninggalan sekutu yang penting lainnya. Lokasi Floating Dock sekarang termasuk dalam wilayah Desa Juangan, Kecamatan Morotai Selatan. Saat ini merupakan pelabuhan fery dan pelabuhan speed. Floating dock adalah dua dermaga 


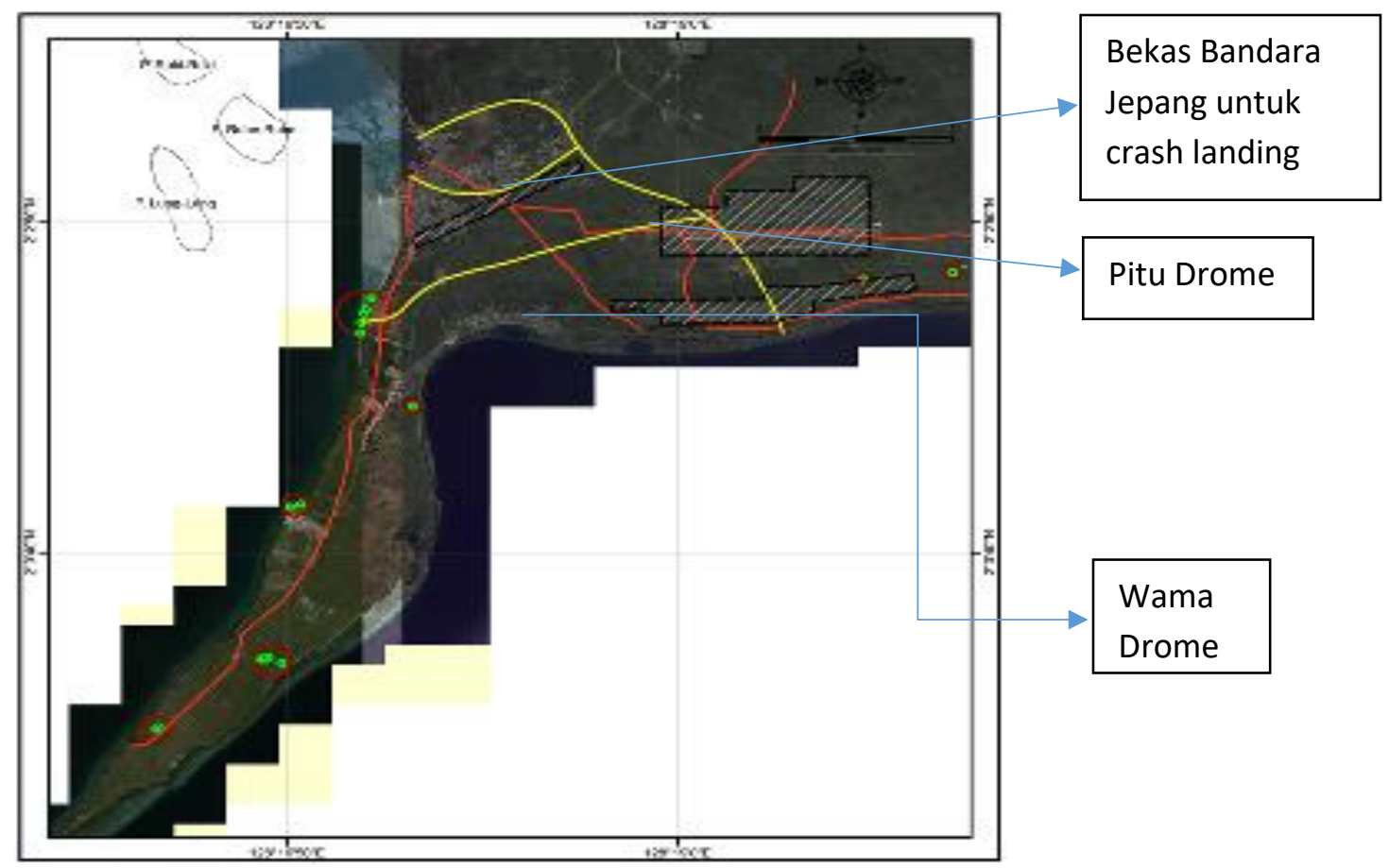

Gambar 7. Hasil overlay peta Morotai Landings, 1944 dengan peta citra satelit Google Eart

(Sumber Dokumentasi Smith, 1953)

apung yang digunakan oleh kapal logistik sekutu dari tahun 1944 sampai 1946, berada di desa Juanga (kini telah menjadi pelabuhan feri dan speedboat). Rancangan konstruksi dermaga apung ini terdiri atas dua bagian, yaitu: dengan cara ditimbun menjorok ke laut memakai bahan pasir, tanah dan batu, selanjutnya dirangkaikan dengan kubus apung atau kayu gelondongan. Keunggulan utama dari jenis dermaga ini adalah tidak tergantung pada ketinggian pasang surut, sehingga dapat mempertahankan hubungan dengan kapal yang ditambatkan (Huwae, 2017).

\section{b. Pitu dan Wama Drome (Landasan Pacu}

Wama drome, adalah landasan pacu sekutu. Pekerjaan pembangunan fasilitas dimulai sebelum Amerika berhasil dikuasai. Prajurit yang bertugas untuk mensurvei lokasi bandara pada 16 September 1944 menghasilkan kesimpulan bahwa perencanaan yang sudah dibuat tidak dapat dilaksanakan. Rencana untuk menyelesaikan bandara yang sudah dibuat oleh Jepang justru diabaikan karena ditakutkan akan mengganggu masterplan bandara besar yang akan dibangun di sebelah timur bandara yang dibuat oleh Jepang. Bandara buatan

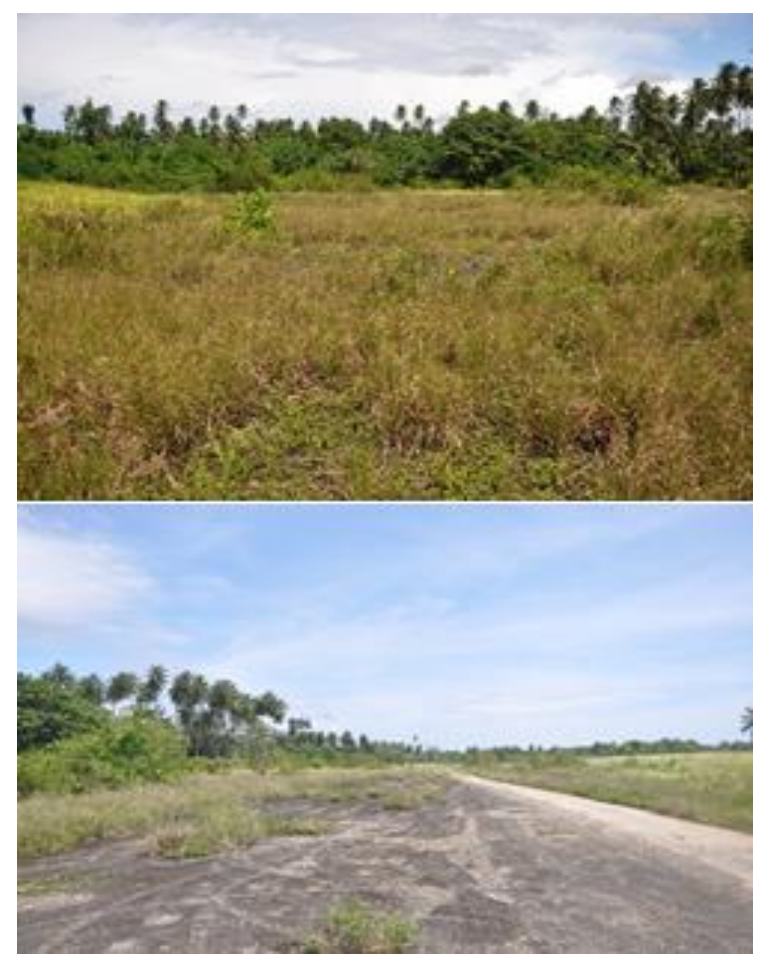

Gambar 8. Kondisi Wama Drome saat ini. (Sumber: Dokumentasi Balar Maluku, 2017) 


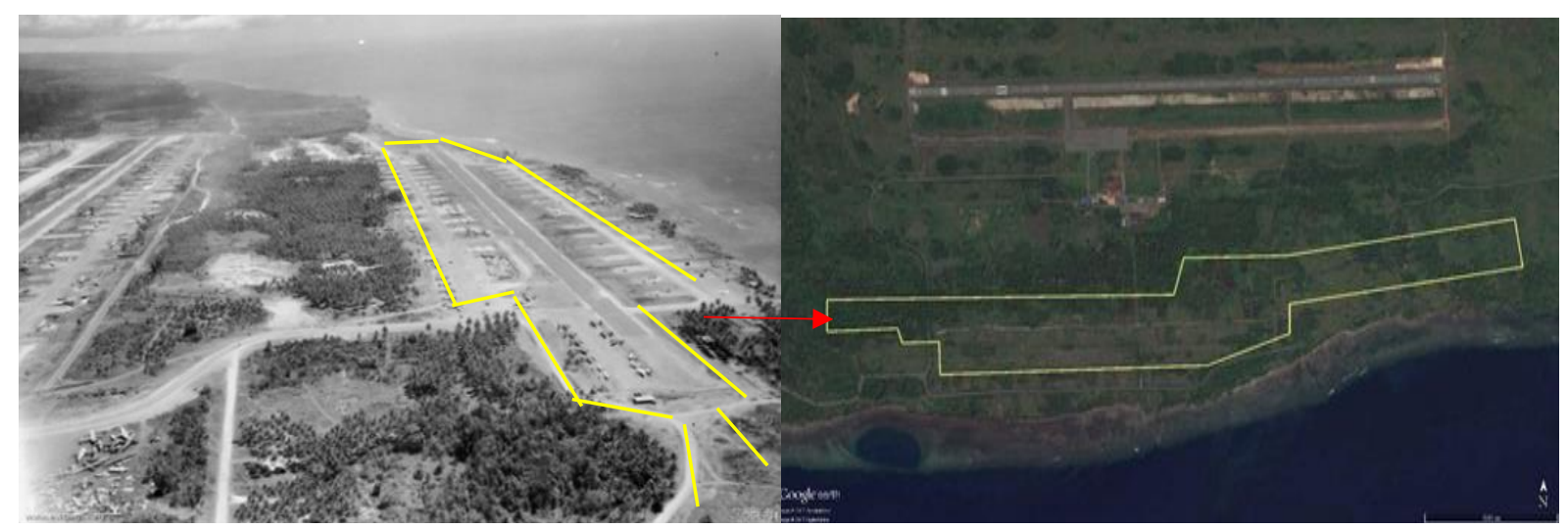

Gambar 9. Wama Drome tahun 1945 (kiri) dan saat ini (kanan)

(Sumber: https://en.wikipedia.org/wiki/Battle_of_Morotai\#/media/File dan Dokumentasi Balar Maluku, 2017).

tentara Jepang diputuskan untuk menjadi bandara darurat yang akan digunakan saat crash landing pekerjaan pada landasan pacu pertama (dinamai Wama drome) dimulai pada 23 September 1944. Sebelum membuka landasan pacu tersebut dilakukan pembersihan, pada 04 Oktober 1944 landasan pacu Wama drome sudah dapat di gunakan dan memiliki panjang 5.000 kaki (1.500 meter) landasan pacu ini bisa dugunakan pesawat pengebom kelas berat (Smith, 1953).

Pembangunan landasan pacu baru (Pitu drome) dimulai pada akhir September, pada 17 Oktober landasan pacu Pitu drome sudah memiliki panjang 2.100 meter, landasan pacu Pitu drome memiliki dua landasan pacu yang sejajar dengan Wama drome. Pada 18 Oktober 1944 pekerjaan pembangunan Pitu drome dipercepat setelah armada angkatan udara Amerika ketiga di bebas tugaskan dari tugasnya yaitu mengamankan pesawat yang akan mendarat di Leyte (Smith, 1953).

Setelah perang berakhir, sekutu masih memiliki pesawat dalam jumlah yang banyak (daripada yang mereka butuhkan), sehingga pesawat-pesawat yang rusak ringan maupun berat ditinggalkan begitu saja, karena sudah tidak diperbaiki lagi, sehingga sampai dasawarsa 1950 - 1960an masih terlihat tumpukan atau deretan pesawat di lapangan terbang tersebut. Wama Airfield terletak di pantai selatan
Morotai, yang letaknya sejajar dengan Pitu Airfield. Juga dikenal sebagai Wama Field dan Wama Drome, lapangan terbang ini secara khusus digunakan untuk pesawat tempur sekutu. Lapangan terbang ini dihubungkan oleh taxiway ke lapangan udara Pitu di dekatnya. Pitu Airfield berada sejajar dengan Wama Airfield, posisinya tepat berada di bagian utara. Juga dikenal sebagai Pitoe Drome. Lapangan terbang ini digunakan untuk operasi atau pesawat pengebom milik sekutu (Smith, 1953).

\section{c. Rumah Sakit dan Kamp-kamp Sekutu}

Berdasarkan survei arkeologi, sebelumnya dilaporkan adanya jejak kamp sekutu di daerah pendaratan sekutu di Tanjung Balitako. Beberapa indikasi yang masih diamati adalah berupa sisa struktur pondasi dan lantai. Di lokasi ini, juga merupakan lokasi pendaratan sekutu, masih tampak sisa-sisa pendaratan sekutu berupa bekas jalan yang dibuat oleh pasukan sekutu pada saat pendaratan. Menurut informasi masyarakat, jalan ini dibuat bersamaan pada saat pendaratan sekutu dan digunakan sebagai jalur rintisan untuk menyerang posisi tentara Jepang di pulau Morotai. Jalur jalan ini dibuat menggunakan sesirtu atau kapur yang terbuat dari pasir batu. Jejakjejak lain yang dapat diamati adalah berupa louvrak yaitu lubang-lubang yang dibuat 


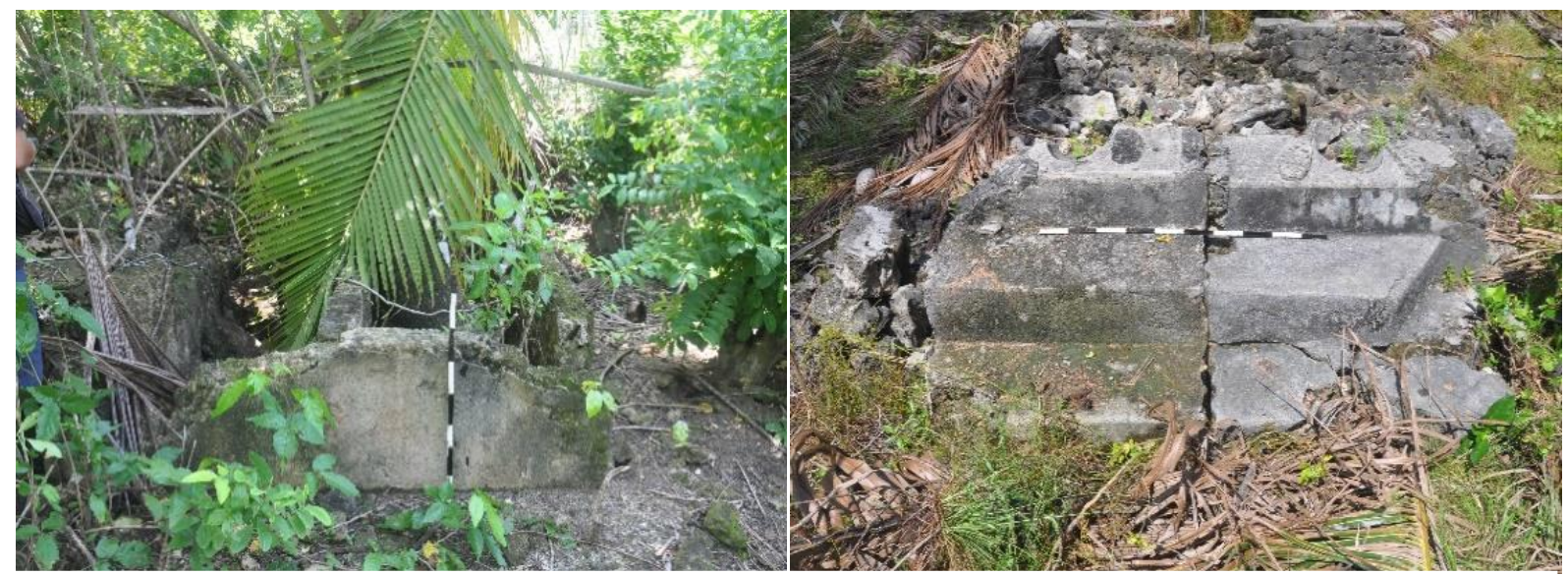

Gambar 10 : Bekas puing-puig struktur bangunan kamp sekutu di tanjung Dehegila

(Sumber: Dokumentasi Balar Maluku, 2017)

oleh tentara Jepang sebagai tempat perlindungan ketika menghadapi pendaratan tentara sekutu (Mansyur, 2013).

Sementara itu tampaknya Tanjung Dehegila, merupakan salah satu pusat kamp sekutu yang lebih permanen dan lebih besar. Di lokasi ini ditemukan sebaran struktur bangunan yang diidentifikasi sebagai rumah sakit dan camp sekutu. Sedikitnya terdapat puluhan puing-puing bekas struktur sisa-sisa bangunan permanen, terdiri dari bahan campuran, pasir, kapur dan batu. Dari puingpuing struktur bangunan yang ditemukan dari hasil survei, dapat didentifikasi sebagai sisa-sisa bak mandi dan toilet, yang kemungkinan merupakan elemen dari fasilitas kamp sekutu dan rumah sakit.

\section{Military Archaeology: Strategi Perang Pasifik di Pulau Morotai}

Arkeologi peperangan (military archaeology) dipahami sebagai konsepsi tentang rekonstruksi peristiwa peperangan berdasarkan rekaman dan analisis arkeologi. Perang pasifik di Morotai meninggalkan jejak-jejak arkeologi perang, baik fasilitas atau infrastruktur perang maupun berbagai fasilitas pendukung, termasuk persenjataan perang. Keberadaan pangkalan militer di Pulau Morotai, berikut berbagai jejak arkeologi fasilitas pendukungnya, dapat disebut sebagai bagian dari menjalankan taktik dan strategi perang, baik dalam sisi kuantitas, penempatan maupun perencanaan waktu penggunaan untuk penyerangan.

Sekutu dibawah pimpinan Mac Arthur mempersiapkan strategi untuk mendirikan suatu pangkalan militer yang luas. Pangkalan militer ini direncanakan berada di daerah teritori musuh dan dari sanalah segala pengaturan strategi penyerangan akan dipusatkan. Mac Arthur menerapkan strategi lompat katak, tanpa mengorbankan banyak jiwa pasukannya dan efisiensi waktu (Mueller, 2012, p. 152; Ojong, 2006, p. 107; Suroto, 2010, p. 93). Perkembangan Pulau Morotai menjadi basis sekutu dimulai tidak lama setelah pendaratan sekutu, dan dua bendara utama telah siap digunakan pada bulan Oktober 1944. Kedua fasilitas ini dan sarana pendukung lainnya memainkan peranan penting pada pembebasan Filipina selama 1944 dan 1945. Kapal-kapal yang menggunakan torpedo dan bandara di Morotai juga mengacaukan posisi Jepang di Indonesia (NEI). Fasilitas-fasilitas dasar yang ada di Morotai kemudian diperlengkapi pada tahun 1945 untuk menunjang penguasaan Pulau Kalimantan yang dipimpin oleh tentara autralia, dan Amerika terus menjadi titik logistik yang penting dan pusat komando sampai tentara Belanda mendapatkan kembali kekuasaan mereka di NEI (Kenney, 1997, pp. 405-415; Smith, 1953, p. 459). Bersamaan dengan kemajuan musuh ke Palau di Pasifik Tengah 
depan, pasukan Jenderal MacArthur di Nugini Barat juga telah mengambil langkah awal dengan mendarat di pulau Morotai yang terletak strategis, di lepas pantai timur laut Halmahera dengan tujuan invasi ke Filipina. Oleh karena itu sangat penting bagi sekutu, melalui pasukan Divisi 32d untuk memindahkan sebanyak mungkin kekuatan dari daerah lain ke Morotai untuk menghancurkan pasukan musuh di sana. Paling tidak, pengembangan dan penggunaan pangkalan udara akan melemahkan kekuatan Jepang. Sekutu menyadari sejak awal bahwa keberhasilan pengembangan basis operasi udara, akan sangat membahayakan pertahanan masa depan Filipina (Willoughby, 1966, p. 277).
Pembangunan cepat yang diterapkan pada Pulau Morotai menjadi sebuah pangkalan militer besar adalah kunci keberhasilan operasi Tradewind (Smith, 1953, p. 475). Tim resimen perang ke 55 dan ke 167 mendarat di red beach dan tim resimen perang ke 124 mendarat di white beach. Setelah sampai di pantai, tentara sekutu langsung menyusun strategi unit mereka dan secara bertahap memasuki daratan Morotai. Pada akhir hari 15 september 1944, sekutu melalu pasukan divisi ke 31 telah mencapai tujuan mereka pada hari tersebut dan segera membuat parimeter (garis batas) seluas 2000 yard $(1800 \mathrm{~m})$ di atas daratan Daruba, yang harus dikuasi oleh pasukan sekutu. Ketika

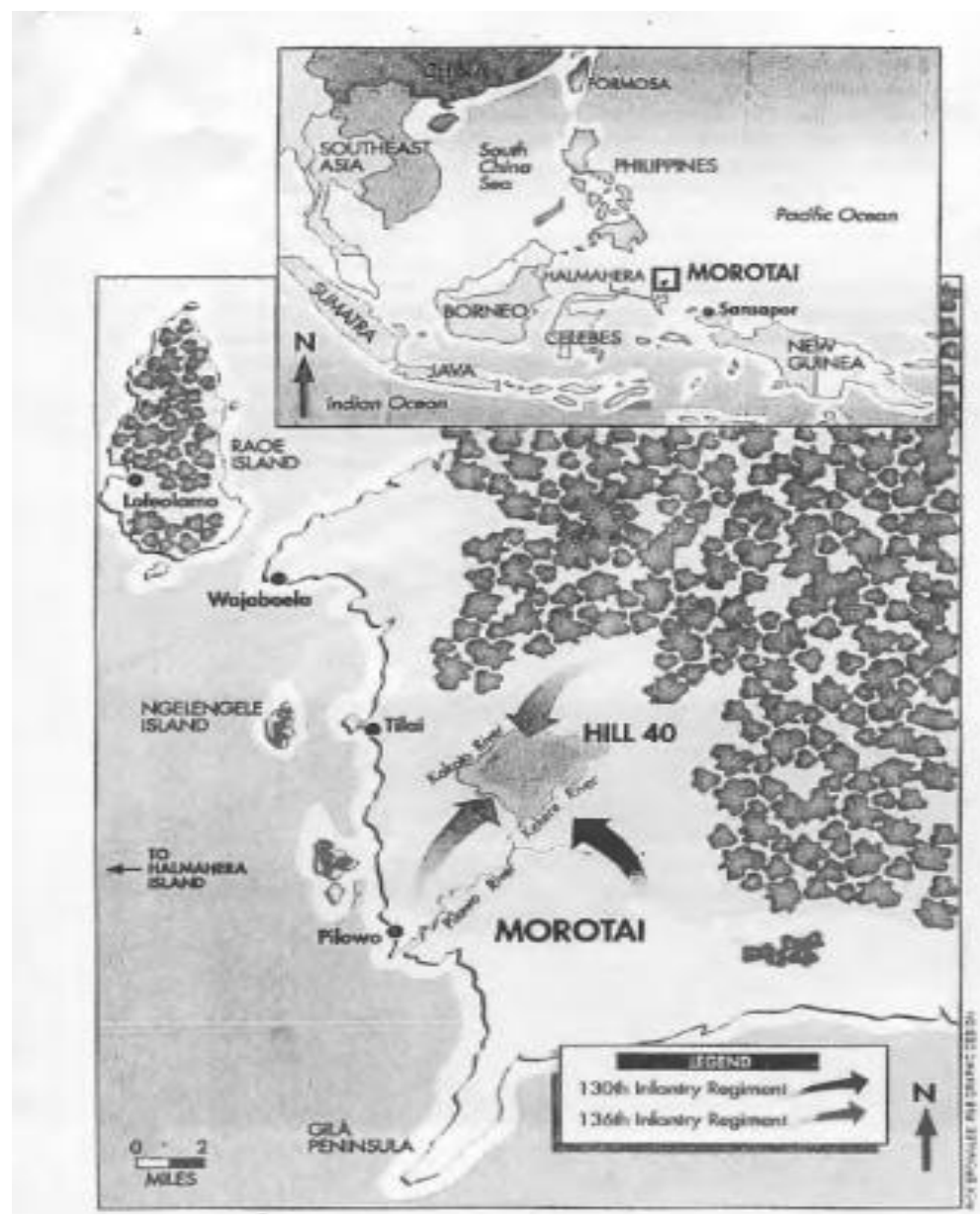

Gambar 11. Serangan Sekutu ke Bukit 40, markas jepang dalam sebuah serangan mendadak oleh Tentara Sekutu.

(Sumber: Dokumentasi Endicott, 1997) 
perlawanan yang diharapkan dari pihak lawan sedikit, perencana perang Sekutu memutuskan untuk mendaratkan pasukan invasi berdekatan dengan lokasi lapangan udara di Dataran Doroeba. Dua pantai di barat daya pulau ini dipilih sebagai lokasi pendaratan yang cocok, dan ditetapkan sebagai Pantai Merah dan Pantai Putih (Smith, 1953, pp. 457-477).

Pembuatan infrastruktur Army dock dengan cara atau metode yang sudah disampaikan sebelumnya, kemungkinan sebagai bagian strategi gerak cepat sekutu menguasai wilayah Daruba. Army Dock dikerjakan dengan cara cepat, karena sebelumnya Pantai Merah (Red Beach) tidak efektif untuk melakukan pendaratan, sehingga infrastruktur Army Dock sangat dibutuhkan untuk memobilisasi peralatan perang dengan lebih mudah dan cepat dengan wilayah sasaran serangan (Hermon, 1968, pp. 481-486; Smith, 1953, pp. 482487; Takou, 2015). Dibuatnya Army Dock yang lebih memungkin untuk pendaratan yang cepat dan armada tank dan peralatan tempur lainnya yang banyak. Semua personil ini didukung oleh engineers dan sebuah grup yang ditujukan untuk mengoperasikan senjata anti serangan udara. Operasi Tradewind juga mengikutsertakan pekerja konstruksi dalam jumlah yang besar dan unit-unit ahli komunikasi yang berperan untuk mempercepat perkembangan Pulau Morotai menjadi sebuah basis utama (Smith, 1953, p. 466).

Strategi gerak cepat dari pasukan sekutu, misalnya juga diperjelas oleh usaha pendaratan yang dijadwalkan pada hari yang sama dengan pendaratan Divisi Marinir ke-1 pada tanggal 15 September 1944, di Peleliu, yang dibarengi dengan proyek-proyek pembangunan infrastruktur baik laut maupun udara. Dalam rangka (1) mempertahankan garis pertahanan dengan keliling 15 mil, (2) mendirikan dan melindungi stasiun radar yang akan ditempatkan di sekeliling pulau, (3) untuk mengamankan pesisir pantai untuk mencegah tentara Jepang yang akan mengirimkan bantuan dari Pulau Halmahera, (4) dan untuk bertahan melawan semua bentuk serangan balik tentara Jepang maka Jenderal MacArthur mempertimbangkan untuk menerjunkan divisi yang diperkuat ditambah tim resimen perang lain (Smith, 1953, p. 464). Jadwal ini memungkinkan divisi utama Armada Pasifik Amerika Serikat untuk secara bersamaan melindungi operasi dari potensi serangan balik Jepang (Taafe, 1998, p. 218).

Interpretasi tentang strategi perang ini, dapat dipelajari berdasarkan peta 1944 (Morotai Landings) dan gerak cepat pembangunan infrastruktur perang, selain berbagai laporan tertulis dari peristiwa perang pasifik. Garis parimeter penguasaan daratan bagian selatan Morotai, adalah strategi sekutu membatasi ruang gerak pasukan Jepang, oleh karenanya pasukan sekutu dapat bergerak memukul mundur pasukan Jepang, hingga akhirnya pasukan Jepang terpaksa memilih mencari tempat aman di daerah-daerah pedalaman dan di bagian utara area yang dikuasai sekutu pada saat itu. Jejak arkeologi berupa pal-pal sekutu dapat ditarik garis merahnya dengan usaha membuat perimeter atau blokade wilayah untuk penguasaan daratan Morotai bagian selatan yang banyak dibangun infrastruktur perang oleh pasukan sekutu.

Dengan demikian, bagi sekutu strategi perang yang paling efektif adalah menguasai udara, dengan pembuatan 2 (dua) lapangan terbang di bagian selatan Pulau Morotai, tentu saja menjadi salah satu kekuatan utama dalam memenangkan pertempuran, selain menguasai laut di bagian selatan Morotai, sebagaimana berbagai penyiapan insfrastruktur militer untuk pendaratan kapal-kapal dan alat-alat pertempuran yang diangkut dari laut. Melihat aspek geografisnya, bagian selatan Pulau Morotai adalah lokasi paling strategis untuk pangkalan militer, selain lanskap lokasi datar, juga tidak berhadapan langsung dengan pusat kekuatan militer Jepang di 
Filipina di bagian utara dari Pulau Morotai. Selain itu dari lokasi bagian selatan Morotai, lebih memudahkan pemantauan terhadap pusat kekuatan Jepang di Pulau Halmahera. Berdasarkan tinggalan arkeologi jejak perang pasifik, terutama infrastruktur laut dan udara, serta berbagai fasilitas pendukung di darat, kata kunci dari strategi perang pasukan sekutu adalah " menguasai udara dan laut untuk kemenangan di darat".

\section{PENUTUP}

Hasil rekonstruksi arkeologi peninggalan perang pasifik di Morotai, terutama obyek-obyek vital infrastruktur perang, dapat menjelaskan bahwa penguasaan infrastruktur merupakan syarat utama strategi sekutu untuk menaklukkan Jepang. Perang Pasifik di Morotai, meskipun dalam waktu yang singkat, namun proyek pembangunan insfrastruktur tergolong masif (besar-besaran). Berdasarkan survei arkeologi, terlihat jelas bahwa Sekutu menyiapkan infrastruktur dengan matang. Infrastruktur untuk kebutuhan tempur dan penyerangan dari udara maupun dari laut, serta fasilitas-fasilitas pendukung untuk kebutuhan pasukan tempur seperti kamp sekutu dan fasilitas kesehatan, merupakan sarana utama yang disediakan militer Jepang untuk merebut menguasai Morotai dalam rangka invasi pusat militer Jepang di Filipina. Pembangunan pangkalan militer, berikut infrastrukturnya seperti lapangan terbang, army dock, kamp sekutu, fasilitas radar untuk komunikasi obyek vital yang dipersiapkan dengan matang.

Sementara itu pembangunan fasilitas itu sendiri merupakan bagian dari strategi sekutu untuk memenangkan perang. Strategi perang dengan gerak cepat tidak hanya didukung pasukan tempur namun juga melibatkan para insinyur dan tenaga-tenaga dalam jumlah masif, merupakan strategi sekutu untuk menguasai dan memenangkan pertempuran dalam perang melawan Jepang. Selain itu pembangunan infrastrukur udara dan laut, merupakan strategi untuk memenangkan pertempuran di darat. Penguasaan wilayah laut dan udara serta membuat garis parimeter di darat cukup efektif, sehingga dalam waktu relatif singkat sekutu berhasil menaklukan Jepang.

Penelitian ini, merupakan upaya rekonstruksi peninggalan perang pasifik yng masih bersifat terbatas. Hal ini karena data utama uyang digunakan, masih sebatas datadata obyek vital, sementara berbagai rekaman arkeologi yang lain, seperti sebaran artefak, masih belum diperhatikan, padahal mengandung informasi tentang sebuag peritiwa perang pada masa lampau, demikan pula dengan sebaran makam-makam sekutu, juga tidak dimasukkan sebagai bagian bahan analisis. Oleh karena itu, kajian ini masih perlu diperluas dan membutuhkan analisis yang lebih mendalam. Demikian pula, berbagai data dokumen ataupun catatancatatan tertulis masih perlu dilacak dan dipelajari untuk memperoleh penjelasan yang lebih maksimal. Selain itu, berbagai narasumber yang ditemui dan diwawancarai masih sangat terbatas, sehingga aspek sejarah tutur belum banyak terungkap, terutama yang berhubungan dengan aspek sosial penduduk lokal.

\section{Ucapan Terima Kasih}

Penulis mengucapkan terima kasih kepada Drs. Muhammad Husni, M.M. selaku Kepala Balai Arkeologi Maluku, terima kasih juga Kepala Badan Arsip dan Perpustakaan Kabupaten Morotai yang mendukung penelitian ini. Terima kasih juga kepada Pak Arifin Kabid Kebudayaan Dinas Pendidikan dan kebudayaan Kabupaten Morotai. Tak lupa terima kasih kepada Natasya Kiki atas bantuan analisis geologinya dan Risno Kurung atas bantuannya selama di lapangan. Ucapan terima kasih tak terhingga kepada Sdr. Syahruddin Mansyur atas diskusi dan masukan-masukan yang memperkaya perspektif makalah ini, serta terima kasih kepada Jurnal Walennae yang berkenan menerbitkan karya tulis ini. 


\section{DAFTAR PUSTAKA}

Airfield and Base Development. Engineers of the Southwest Pacific. (1951). In Office of the Chief Engineer, General Headquarters, Army Forces Pacific. Washington DC: US Government Print.

Bleed, P., \& Scott, D. D. (2011). Contexts for Conflict: Conceptual Tools for Interpreting Archaeological Reflections of Warfare. Journal of Conflict Achaeology, 6(1), 4264.

Djafaar, I. A. (2005). Dari Moloku Kie Raha hingga Negara Federal: Iskandar Muhammad Djabir Syah, Biografi Politik Sultan Ternate. Yogyakarta: Bio Pustaka.

Handoko, W., Husni, M., Arsthen, G. P., Natasya, R., \& Kurung, R. (2017). Rekonstruksi Arkeologi Perang Pasifik di Pulau Morotai. Ambon.

Hermon, G. G. (1968). Royal Australian Navy 1942-1945. Canberra: Australian War Memorian.

Huwae, A. (2017). Peninggalan Arkeologi Perang Dunia II di Pulau Morotai. Ambon.

Kenney, C. G. (1997). George Kenney Report. A Personal History of Pacific War. In Air Force History and Art Museum Program. Washington: United State Army.

Mansyur, S. (2012). Pulau Buru Masa Perang Dunia II: Perspektif Arkeo-Historis. Kapata Arkeologi, 8(1), 43-50.

Mansyur, S. (2013). Tinggalan Perang Dunia II dan Konseptualisasi Museum di Morotai. Kapata Arkeologi, 9(1), 1-12.

Maurer. (1983). Air Combat Unit of World War II. (Maurer, Ed.). Washington DC: Office of Air Force History.

Mueller, J. N. (2012). Guadalcanal 1942 Jepang vs Amerika di Ujung Pasifik. Jakarta: Kepustakaan Populer Gramedia.

Murray, W., \& Millett, A. R. (2001). A War to be Won: Fighting the Second World War. London: Harvard University Press.

Ojong, P. K. (2006). Perang Pasifik (Cetakan IX). Jakarta: Penerbit Buku Kompas.

Parera, M. A., Usmany, D. P., \& Sinaga, R. (2013). Sausapor : Saksi Sejarah Perang Dunia II di Kabupaten Tambrauw, Provinsi Papua Barat. Yogyakarta: Kepel Press.

Rahman, A. (n.d.). Morotai : Pulau Terlupakan dalam Sejarah Perang Pasifik di Indonesia, 1944-1945. Retrieved March 23, 2018, from https://www.academia.edu/15242907/Morotai_Pulau_Terlupakan_Dalam_Sejarah _Perang_Pasifik_Di_Indonesia)

Rottman, G. L. (2002). World War II Pasific Island Guide. London: Green Wood Press.

Smith, R. R. (1953). The Approach to the Philippines. In United States Army in World War II: The War in the Pacific. Washington DC: United States Army Center of Military History.

Suroto, H. (2010). Jayapura Pada Era Perang Pasifik. Jurnal Papua, 5(1), 91-100. 
Taafe, S. R. (1998). MacArthur's Jungle War. The 1944 New Guinea Campaign. Lawrence: University Press of Kansas.

Takou, M. (2015). Perang Pasifik Dalam Ingatan Penduduk Morotai September 1944 - Agustus 1945. Jurnal Elektronik Fakultas Sastra, 1(1).

Vencl, S. (1984). War and warfare in Archaeology. Journal of Anthropological Archaeology, $3(2), 116-32$.

William P. Endicott. (1997). Morotai Stepping Stone to the Philippines.”World War II. Retrieved March 25, 2018, from ttp://www.33rdinfantrydivision.org/documents/morotai_article_endicott.pdf

Willoughby, C. A. (1966). Japanese Operations in the Southwest Pacific Area Volume II - Part I. In Reports of General MacArthur. Washington DC: United States Government Printing Office. 